Mutation Research, 58 (1978) 217-223

(C) Elsevier/North-Holland Biomedical Press

\title{
MUTAGENICITY OF ALIPHATIC EPOXIDES
}

\author{
D.R WADE, S C AIRY and J.E. SINSHEIMER * \\ College of Pharmacy, University of Michigan, Ann Arbor, MI 48109 (U S.A) \\ (Received 18 April 1978) \\ (Revision received 11 July 1978) \\ (Accepted 20 July 1978)
}

\section{Summary}

The mutagenicity of 17 alıhatic epoxides was determined using the specially constructed mutants of Salmonella typhimurium developed by Ames. The activity of these epoxides together with those reported in the literature as mutagens in strains TA100 and TA1535 depended on the degree of substitution around the oxirane ring. Monosubstituted oxiranes were the most potent mutagens in both strains. 1,1-Disubstitution resulted in the complete loss or reduction of mutagenicity. trans-1,2-Disubstituted, and tetrasubstituted oxiranes all lacked mutagenicity, while the cis-1,2-disubstituted oxiranes tested were weakly mutagenic in strain TA100 only. For the monosubstituted compounds the r resence of electron-withdrawing substituents increased mutagenicity.

\section{Introduction}

Parallel to the biotransformation of arene oxides from aromatic compounds [5], it is assumed that alıphatic epoxides (alkene oxides) are active intermediates in the metabolism of alkene compounds [15]. The concept that arene oxides, through their binding to biopolymers such as DNA, RNA and protem, are responsible for the toxic, carcinogenic, and mutagenic effects of aromatic compounds is well established [5,9]. However, as pointed out by Oesch [13], it does not follow that the adverse properties of some arene oxides can be extrapolated to epoxides in general.

This is the case in the Ames test for mutagenicity of alkene oxides. Thus, it has been reported that 2,3-epoxypropionaldehyde, 2,3-epoxypropanol, styrene oxide, 1,2-epoxybutane, 1,2,3,4-diepoxybutane, and 1,2,7,8-diepoxyoctane [11] as well as chloroethylene oxıde [10] are mutagenic. While cts- and trans-4-

* To whom correspondence should be addressed 
acetylaminostilbene- $\alpha, \beta$-oxide [6] as well as carbamazepıne-10,11-oxıde, cyporheptadine-10,11-oxide, and cyclobenzaprine-10,11-oxide are not mutagenic [7].

It is the purpose of this investigation to extend mutagenicity testing of alkene oxides in the Ames assay so as to better predict the toxicity of such compounds per se and as an initial step in evaluating their possible role in the toxicity of alkene compounds subsequent to biotransformation.

\section{Materials and methods}

The following epoxides were obtained from the sources indicated in the purest grade avallable and their structures were confirmed by n.m.r. spectrometry. 3,3,3-Trichloropropylene oxide (purity 98\%), 1-bromo-2,3-epoxypropane (b.p. $134-136^{\circ} \mathrm{C}$ ), 1-chloro-2,3-epoxypropane (purity $99+\%$ ), 1,2-epoxy3-fluoropropane (purity 98\%), propylene oxıde (purity 99\%), styrene oxide (purity 97\%), trans-stilbene oxide, cyclohexene oxide (purity 98\%), and glycldol (b.p. $160-161^{\circ} \mathrm{C}$ ) were obtained from Aldrich Chemical Co. 2,3-Epoxybutane, $\alpha$-methylstyrene oxide and 1,2-epoxyisobutane were obtained from ICN Life Sciences Group.

$\alpha$-Phenylstyrene oxide (m.p. $55-57^{\circ} \mathrm{C}$; Ref. [4], 54-56 ${ }^{\circ} \mathrm{C}$ ) and 2-methyl3,3,3-trichloropropylene oxide (b.p. $57^{\circ} \mathrm{C} / 0.6 \mathrm{~mm}$ ) were syntheฯized from benzophenone and 1,1,1-trichloroacetone by the general procedurn described by Corey and Chaykovsky [4].

cis-Stilbene oxide was prepared by dehydrohalogenation of threo-2-chloro1,2 -diphenylethanol with $1.0 \mathrm{~N} \mathrm{NaOH}$. The threo isomer was synthesized by the procedure described by Bertı et al. [3].

trans-Diethylstilbestrol (DES) oxıde (m.p. $142-143^{\circ}$; Ref. [16], $145^{\circ} \mathrm{C}$ ) was prepared from trans-DES by reaction with peracetic acid in a modified procedure of Wessely et al. [16] in which the oxide was isolated only after the removal of acids to prevent the pinacolone rearrangement noted in the original procedure.

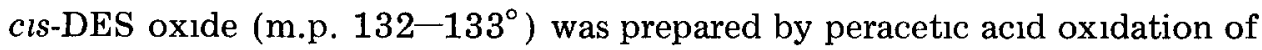
$c \iota s$-DES in dimethylsulfoxide. The $c l s$-DES was obtained by isomerization of the trans-isomer in dimethylsulfoxide by the procedure of White and Ludwig [17].

Mutagenesis assays were performed as described by Ames [2]. Bacteria used in the assay were histidine-dependent mutants of Salmonella typhimurium, strains TA1537, TA1535, TA100 and TA98 supplied by Professor B.N. Ames, Berkeley, CA. The cells were grown overnight in nutrient broth (Difco) at $37^{\circ} \mathrm{C}$. Test compounds dissolved in $0.1-0.5 \mathrm{ml}$ dimethylsulfoxide were added to $2 \mathrm{ml}$ of top agar [1] along with $0.1 \mathrm{ml}$ of the bacterial suspension (2-4X $10^{8}$ cells) and plated in duplicate on petri dishes with semi-enriched agar (Vogel and Bonner minimal medium E) as described [2]. Control plates were treated in the same manner, but recelved only dimethylsulfoxide in place of the test compound. The revertant colonies were counted after incubation for 2 days at $37^{\circ} \mathrm{C}$ and a dose-response curve established for all positive compounds. Doseresponse curves were confirmed by repeated determinations.

Benzo $[a]$ pyrene, $\beta$-naphthylamine and methyl methanesulfonate were rou- 
TABLE 1

MUTAGENICITY AND STRUCTURE OF ALIPHATIC EPOXIDES

\begin{tabular}{|c|c|c|c|c|}
\hline \multicolumn{5}{|c|}{ Monosubstituted } \\
\hline \multirow[t]{2}{*}{ No } & \multirow[t]{2}{*}{ Structure } & \multicolumn{2}{|c|}{ Mutagenıcity ${ }^{a}$} & \multirow[t]{2}{*}{ Ref } \\
\hline & & TA100 & TA1535 & \\
\hline 1 & & $2355 / 500$ & $131 / 500$ & $\mathbf{A}^{\mathbf{b}}$ \\
\hline 2 & & $1502 / 500$ & $456 / 500$ & $\mathbf{A}$ \\
\hline 3 & & $674 / 500$ & $402 / 500$ & $\mathbf{A}$ \\
\hline 4 & & $766 / 500$ & $265 / 500$ & $\mathbf{A}$ \\
\hline 5 & & $897 / 500$ & $34 / 500$ & $\mathbf{A}$ \\
\hline 6 & & $1120 / 200$ & $622 / 200$ & A/11 \\
\hline 7 & & $166 / 1500$ & $22 / 1000$ & $\mathbf{A}$ \\
\hline 8 & & $5260 / 20$ & $+\mathbf{c}$ & 11 \\
\hline 9 & & $\mathrm{NR}^{\mathrm{d}}$ & $61 / 04^{\mathrm{e}}$ & 10 \\
\hline 10 & & $333 / 4200$ & + & 11 \\
\hline 11 & & $690 / 900$ & + & 11 \\
\hline 12 & & NR & $71 / 50$ & 11 \\
\hline \multicolumn{5}{|c|}{ 1,1-Disubstituted } \\
\hline \multirow[t]{2}{*}{ No } & \multirow[t]{2}{*}{ Structure } & \multicolumn{2}{|l|}{ Mutagenicity } & Ref. \\
\hline & & TA100 & TA1535 & \\
\hline 13 & $\mathrm{Cl}_{3}$ & $560 / 500$ & $\mathrm{~nm}-1000^{f}$ & $\mathbf{A}$ \\
\hline 14 & & $\mathrm{~nm}-5000$ & $\mathrm{~nm}-5000$ & $\mathbf{A}$ \\
\hline 15 & & $\mathrm{~nm}-\mathbf{5 0 0 0}$ & nm-5000 & $\mathbf{A}$ \\
\hline 16 & & $\mathrm{~nm}-2000$ & $\mathrm{~nm}-2000$ & $\mathbf{A}$ \\
\hline
\end{tabular}


TABLE 1 (continued)

1,2-Disubstituted

No. Structure

Mutagenicity

Ref

TA100

TA1535

17<smiles>c1ccc(C2OC2c2ccccc2)cc1</smiles>

$79 / 100^{\mathrm{g}}$

nm-100

A

18<smiles>C1CCC2OC2C1</smiles>

$100 / 1000$

nm-1500

A

19

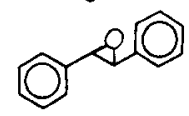

20

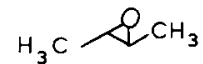

nm-100

nm-100

A

nm-500

$\mathrm{nm}-5000$

A<smiles>[CH]=CNc1ccc(C2OC2c2ccccc2)cc1</smiles>

$\mathrm{nm}-100$

$\mathrm{nm}-100$

6

nm-1 00

nm-100

6

ACHN

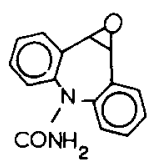

NR

$\mathrm{nm}-\mathbf{5 0 0}$

7

NR

nm-100

7

NR

$\mathrm{nm}-500$

7

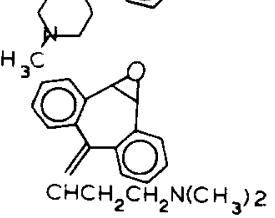

Tetrasubstıtuted

\begin{tabular}{|c|c|c|c|c|}
\hline \multirow[t]{2}{*}{ No } & \multirow[t]{2}{*}{ Structure } & \multicolumn{2}{|c|}{ Mutagenicity } & \multirow[t]{2}{*}{ Ref } \\
\hline & & TA100 & TA1535 & \\
\hline 26 & & nm-100 & nm-100 & $A^{h}$ \\
\hline 27 & & $\mathrm{~nm}-100$ & $n m-100$ & $A^{h}$ \\
\hline
\end{tabular}


tinely included as positive controls. Benzo[a]pyrene and $\beta$-naphthylamine required the addition of a rat-liver homogenate and a NADPH-generating system prepared as described by Ames [2]. Bacterial survival was determined by plating bacterial dilutions on nutrient agar (Difco) with the test compound. With the exception of $c \iota s$-stilbene oxide no reduction of bacterial growth was observed in the linear portion of the dose-response curve.

\section{Results}

Table 1 summarizes the mutagenicity results in strains TA1535 and TA100 for compounds investigated in the present study and those previously reported in the literature. All the compounds in our study, with the exception of 2-methyl-3,3,3-trichloropropylene oxide (13), cis-stilbene oxide (17) and cyclohexene oxide (18) that were mutagenic in strain TA100 were also mutagenic, but with reduced sensitivity, in the second strain, TA1535. Both of these strains detect base-pair mutagens. However, none of the epoxides in the present study were found to be mutagenic in strains TA1537 and TA98 which detect frame-shift mutagens.

All the monosubstituted epoxides tested in the present study were mutagenic (1-7). Other monosubstituted epoxides previously reported to be mutagenic by the Ames assay include compounds 8-12. The only disubstituted epoxides found to be mutagenic were 2-methyl-3,3,3-trichloropropylene oxide (13), cls-stilbene oxide (17) and cyclohexene oxide (18). Mutagenicity for these three compounds was restricted to strain TA100. The other 1,1-disubst1tuted and trans-1,2-disubstituted epoxides tested $(14-16,19,20)$ as well as reported (22) were found to be nonmutagenic. Neither of the tetrasubstituted epoxides $(26,27)$ were found to be mutagenic.

In the monosubstituted series, those compounds with electron-withdrawing groups on the oxirane ring proved to be the more potent mutagens.

\section{Discussion}

The results indicate that the monosubstituted epoxides are the most potent mutagens and that even the addition of a single methyl group to the oxirane

\footnotetext{
a Mutagencity is reported as revertants munus spontaneous revertants per micrograms of compound unless otherwise stated The microgram quantity is taken from the linear portion of the dose-response curve Average spontaneous revertants were 180 for staln TA100, 20 for TA1535, 39 for TA98 and 7 for TA1537 Positive controls used included $5 \mu \mathrm{g}$ benzo[a]pyrene (131 revertants/TA1537 and 425 revertants/TA98), $02 \mu l$ methyl methanesulfonate (2150 revertants/TA100) and $100 \mu \mathrm{g} \beta$-naphthylamine (500 revertants/TA1535). Benzo[a]pyrene and $\beta$-naphthylamine required, for mutagenic activity, the addition of a rat-liver homogenate and a NADPH-generating system prepared as described in Ref 2 .

$b_{A}=$ this study

c Reported as mutagenic in Ref 11 , but no accompanying data

d Not reported.

e Reported in Ref 10 as 61 revertants per plate at a dose level of $04 \mu \mathrm{moles} / \mathrm{ml}$ of soft agar layer

f Nonmutagenic at the highest dose tested in $\mu \mathrm{g}$

Results are expressed in terms of the highest concentration with minimal (18\%) toxicity

$h$ Diethylstilbestrol- $\alpha, \beta$-oxide of unspecified stereochemistry has been reported as being nonmutagenic in Ref 12
} 
ring can reduce or eliminate mutagenicity. A reduction in mutagenicity in strain TA100 is demonstrated in the comparison of compound 13 to the strong mutagen 3,3,3-trichloropropylene oxide (1). The elımination of mutagenıcity with the addition of a methyl substituent is demonstrated in both strains with a comparison of compounds 15 and 20 to propylene oxide (7) as well as in the comparison of 14 to styrene oxide (5).

For the monosubstituted compounds, mutagenicity appears to be related to the electrophilicity of the epoxide. Electron-withdrawing groups on the epoxide would create a stronger electrophile with increased reactıvity to bionucleophiles such as DNA. The electron-withdrawing groups present in compounds 1 through 6 as well as 8 and 9 do result in an increase in mutagenicity for these compounds compared to propylene oxide (7) in both TA100 and TA1535. Compound 10 in comparison to 7 can be considered to have an electron-donating group present and on a per microgram basis has decreased mutagenicity. However, the strength of the elctron-withdrawing group alone cannot always be correlated to the extent of mutagenıcity. For example, while trichloropropylene oxide (1) is more mutagenic than the monochloro compound 3 in strain TA100, the reverse is true in TA1535.

It is of interest that the only 1,2-disubstituted epoxides that were found to be mutagenic were cls-stilbene oxıde (17) and cyclohexene oxide (18) with mutagenicity in both cases being restricted to strain TA100. The number of revertant colonies for both compounds was low and for cls-strlbene oxide (17) the results are further comphcated by the inability to establish a meaningful doseresponse range due to cell toxicity. Compounds $21,23-25$ have a similar cis arrangement of substituents on the oxirane ring as do compounds 17 and 18 yet have been reported as being nonmutagenic in the Ames assay [6,7]. More compounds of the cls stereochemistry must be tested to better define the mutagenicity of these disubstituted compounds.

The structure-activity relationships indicated in our results are similar in several respects to those reported by Oesch [14] in his study of the specificity of epoxides as substrates and inhibitors of epoxide hydratase. In both ours and Oesch's studies, reactivity was most pronounced for the monosubstituted oxides, and for the 1,2-disubstituted compounds only the cls but not the trans compounds were active. In both studies, tetrasubstituted compounds were inactive.

The two studies differed, however, in that there was a lipophilic substituent effect for compounds most effective in the hydratase study that is not evident in the mutagenicity response. Also, 1,1-disubstituted compounds are active in the hydratase investigation but, except for compound 13 in strain TA100, are nactive as mutagens.

Some of the same alkene oxides and related compounds have been tested as substrates for glutathione-S-epoxide transferase [8]. The relationships noted for their substrate-transferase activity do not always parallel the structuremutagenicity results. For example not all the monosubstituted epoxides, including the relatively strong mutagenic compounds 6 and 8 , were substrates for glutathione transferase, while also in contrast to the mutagenicity series, most of the multisubstituted compounds tested were active substrates for the transferase. 
Thus, it is of interest that structure-activity for neither of the two principal epoxide detoxification mechanısms completely parallel toxicity as measured by the Ames mutagenicity test. A knowledge of all three systems is required to make predictions concerning the in vivo toxicity of a given alkene oxide. Such information would be important for the proper handling as well as for the design of useful alkene oxides and their parent alkene compounds of reduced toxicity.

\section{Acknowledgements}

The authors wish to express appreciation to Professor B.N. Ames, Berkeley, CA for supplying the Salmonella mutants. We are grateful to Kathleen Drinan for technical assistance. This work was supported in part by Grant GM 19815 from the National Institutes of Health, Bethesda, MD.

\section{References}

1 Ames, B N, F D Lee and W E Durston, An improved bacterial test system for the detection and classification of mutagens and carcinogens, Proc Natl Acad. Sc1 (U.S.A ), 70 (1973) $782-786$

2 Ames, B N, J McCann and E Yamasak,, Methods for detecting carcinogens and mutagens with the Salmonella/mammalian-microsome mutagenicity test, Mutation Res, 31 (1975) 347-364.

3 Bertı, G., F Bottan, P Ferrarinı and B Macchia, Stereochemistry of the additions of acids to stilbene and styrene oxides, $J$ Org Chem , 30 (1965) 4091-4096

4 Corey, $\mathrm{E} \mathrm{J}$ and $\mathrm{M}$ Chaykovsky, Dimethylox osulfonium methylide $\left(\left(\mathrm{CH}_{3}\right)_{2} \mathrm{SOCH}_{2}\right)$ and dimethylsulfonum methylide $\left(\left(\mathrm{CH}_{3}\right)_{2} \mathrm{SCH}_{2}\right)$, Formation and application to organic synthesis, $J$ Am Chem. Soc, 87 (1965) 1353-1364

5 Daly, J.W, D M Jenna and B. Witkop, Arene oxıdes and the NIH shıft The metabolism, toxicity and carcinogenicity of aromatic compounds, Expenentia, 28 (1972) 1129-1149.

6 Glatt, H R , M Metzler, H G Neumann and F Oesch, Metabolic epoxidation of trans-4-acetylaminostilbene A pxotective mechanism against its activation to a mutagen, Biochem. Biophys. Res. Commun, 73 (1976) 1025-1029

7 Glatt, H R , F Oesch, A Frigerio and S Garattını, Epoxides metabolically produced from some carcinogens and from some clinically used drugs, Int J Cnacer, 16 (1975) 787-797

8 Hayakawa, T., S. Udenfriend, H. Yagi and D.M. Jerina, Substrates and inhibitors of hepatic glutathione-S-epoxide transferase, Arch. Blochem Biophys, 170 (1975) 438-451

9 Jenna, D.M and $J W$ Daly, Arene oxides A new aspect of drug metabolism, Science, 185 (1974) 573-582

10 Malavellle, C, H. Bartsch, A. Barbin, A.M. Camus, R. Montesano, A. Croisy and P. Jacquignon, Mutagenicity of vinyl chloride, chloroethylene oxide, chloroacetaldehyde and chloroethanol, Biochem Biophys. Res Commun, 63 (1975) 363-370.

11 McCann, J,E. Chol, E Yamasakı and B N Ames, Detection of carcinogens as mutagens in the Salmonella/microsome test Assay of 300 chemicals, Proc Natl Acad Sci (U.S.A ), 72 (1975) 51355139

12 Neumann, H G., M. Metzler and W. Topner, Metabolıc activation of diethylstıbestrol and amınostılbene dernvatives, Arch. Toxicol , 39 (1977) 21-30

13 Oesch, F, Metabolic transformation of clinically used drugs to epoxides New perspectives in drugdrug interactions, Biochem Pharmacol, 25 (1976) 1935-1937

14 Oesch, F, Purfication and specificity of a human microsomal epoxide hydratase, Biochem. J, 139 (1974) $77-88$

15 Testa, B, and P. Jenner, Drug metabolism Chemical and Biochemical Aspects, Dekker, New York, 1976, pp 56-61.

16 Wessely, F.V., E. Kerschbaum, A. Kleedorfer, F. Prillınger and E Zajıc, Uber synthetische Oestrogene. I Monatsh. Chem., 73 (1940) 127-158.

17 White, W.A., and N.H Ludwig, Isomenzation of $\alpha, \alpha^{\prime}$-diethylstılbestrol, 1solation and charactenzation of the cus-1somer, J. Agr. Food Chem, 19 (1971) 388-390. 